\title{
RESILIENSI PADA KELUARGA YANG MEMPUNYAI ANAK DISABILITAS:
}

\section{REVIEW}

\author{
Esti Widya Rahayu \\ Universitas Muhammadiyah Malang \\ estiwidya27@gmail.com
}

\begin{abstract}
ABSTRAK: Artikel ini bertujuan untuk melakukan review terhadap penelitian tentang karakteristik resiliensi pada keluarga yang mempunyai anak disabilitas yang meliputi tinjauan terhadap latar belakang keluarga, berbagai jenis disabilitas, dan rancangan penelitian. 11 hasil penelitian, digunakan untuk mereview dengan publikasi jurnal internasional antara tahun 2015-2018. Karakteristik subjek penelitian tidak hanya berasal dari keluarga inti, namun bibi, kakek, nenek yang memiliki anak disabilitas dengan berbagai kriteria seperti disabilitas intelektual, autis (ASD), down syndrome, dan anak dengan kriteria disabilitas lain. Hasil dari review, menunjukkan bahwa resiliensi berperan sebagai faktor pelindung keluarga dalam beradaptasi dan menghadapi anak disabilitas pada kehidupan sehari-hari. Penelitian dilakukan di berbagai negara seperti India, Amerika, Korea untuk mengukur resiliensi pada keluarga. Metode yang sering digunakan dalam penelitian ini ialah survey, komparatif, dan yang lain menggunakan wawancara. Pembahasan mengenai hasil review, berimplikasi bagi penelitian selanjutnya yang dapat dilakukan di Indonesia.
\end{abstract}

Kata Kunci: review; resiliency in family; maternal; paternal; children disability

ABSTRAC: This article discusses research on the characteristics of resilience in families that have children with disabilities that discuss family backgrounds, various types of disabilities, and research designs. 11 results of the study were used to review international journal publications between 20152018. The characteristics of the research subjects were not only from the nuclear family, but also aunts, grandfathers, grandmothers who had children who were compatible with various criteria such as disability, autism (ASD), down-syndrome, and children with other disabilities. The results of the review indicate facts taken as a family protective factor in discussions and discussing children's problems in daily life. The research was conducted in various countries such as India, America, Korea to measure resilience in families. The method often used in this study is a survey, then comparative, and others use interviews. Discussion regarding the results of the review, it has implications for further research that can be done in Indonesia.

Kata Kunci: review; resiliency in family; maternal; paternal; children disability

\section{PENDAHULUAN}

Anak yang mengalami disabilitas, ialah mereka yang secara fisik, psikis, kognitif, dan sosial mengalami hambatan dalam mencapai kebutuhannya secara maksimal, dalam hal ini meliputi mereka yang tuli, buta, mempunyai gangguan bicara, cacat fisik, retardasi mental, dan gangguan emosional (Suran \& Rizzo dalam Mangunsong, 2009). Diagnosis kecacatan sering dianggap sebagai pengalaman traumatis bagi keluarga dan mempengaruhi kehidupan, emosi, dan perilaku mereka (Erguun \& Ertem, 2012). Tantangan dan 
tuntutan pengasuhan dalam sehari-hari merupakan penyebab stres pada orang tua yang paling signifikan (Crnic \& Low dalam Wong., dkk, 2015). Terkadang, orang tua menerima sepenuhnya mengenai keadaan anaknya yang berkebutuhan khusus, namun sebagian besar tekanan sehari-hari yang didapatkan dari ketidakmampuan atau disabilitas oleh anak dapat mengakibatkan penolakan terhadap anak tersebut (Kakavand A dalam Hadizad, 2016).

Hubungan dalam keluarga
memberikan pengaruh yang besar untuk membangun relasi dengan orang lain dan adanya sumber daya yang potensial untuk menjadi resilien (Walsh, 2016). Penilaian pada keluarga yang berorientasi pada resilien, berarti mengupayakan anggota keluarga dapat berkembang secara positif yang di dalamnya terdapat anak-anak berkebutuhan khusus maupun beresiko, dengan demikian memiliki kepercayaan pada kemampuan yang dimiliki, adanya dukungan dari upaya yang dimiliki, dan mendorong keluarga untuk memanfaatkan kehidupan dengan sebaik-baiknya. Pada keluarga dengan kondisi yang memiliki anak berkebutuhan khusus, kontribusi positif dapat diberikan melalui orang tua, saudara kandung, kakek, nenek, paman, bibi, dan anggota keluarga lain yang memainkan peranan dalam mendukung situasi yang mengancam (Walsh, 2016).
Keluarga terutama orang tua sebagai agen sosial anak yang utama selayaknya harus memperhatikan kebutuhan anaknya. Ketika mendapati sebuah kesulitan, keluarga tidak hanya bereaksi akan hal tersebut melainkan juga melakukan pendekatan terhadap tantangan yang menjadi sumber stres mereka hal ini dapat menekan dampak stres yang akan terjadi. Cara yang digunakan dalam keluarga untuk mengelola pengalaman-pengalaman yang mengganggu, kesulitan, stres, akan mempengaruhi adaptasi pada semua anggota keluarga dan relasi mereka dengan orang lain. Proses transaksional dalam anggota keluarga ini merupakan sebuah langkah yang proaktif untuk mengurangi disfungsi dan menciptakan adaptasi yang positif untuk menghadapi tantangan di masa depan (Walsh, 2016).

Pada orang tua yang mengalami situasi menegangkan ketika mengasuh anak disabilitas muncul kecemasan mengenai masa depan anak, pengalaman stigma sosial, keterbatasan dalam bersosial dan karier, adanya hubungan yang canggung dengan orang sekitar, kendala keuangan, kesejahteraan dan emosional yang buruk, dan kurangnya layanan yang memadai (Chadwick dalam Rajan, Srikhrisna, \& Romate 2016). Tantangan hidup yang terus menerus, pada gilirannya dapat memengaruhi hubungan antar anggota 
keluarga, dengan demikian kegagalan fungsi dalam sebuah keluarga dapat terjadi (Walsh, 2016).

Pengalaman yang menegangkan dan dapat memicu stres ini, merupakan hal yang harus ditangani. Oleh karena itu, dibutuhkan kemampuan untuk menghadapinya. Kemampuan ini dapat disebut sebagai resiliensi, yaitu kemampuan dalam menghadapi perkembangan dan adaptasi terhadap pengalaman yang menegangkan. Resiliensi juga tidak hanya sekedar mengatasi suatu masalah atau bertahan dari cobaan, resiliensi jugga melibatkan adaptasi yang positif, berkembang kembali, dan adanya perubahan dalam diri dan relasi melalui berbagai pengalaman sehingga individu dapat berkembang secara positif (Tedeschi \& Calhoun, 2004). Orang tua maupun keluarga yang memiliki kemampuan untuk mengatasi keadaan dengan hasil yang baik dan positif, dapat meningkatkan hubungan antara orang tua dan anak.

$$
\text { Beberapa penelitian, telah }
$$
menemukan bahwa keluarga yang melalui kesulitan dan berjuang untuk melaluinya, sering kali lebih kuat, memiliki kasih sayang yang besar, dan mempunyai cara yang lebih banyak dalam menghadapi tantangan di masa depan. Perspektif resiliensi pada keluarga didasarakan pada keyakinan yang mendalam pada potensi keluarga untuk memperkuat resiliensi mereka dalam menghadapi tantangan di kemudian hari. Keluarga yang telah memiliki pengalaman traumatis, masih memilki potensi untuk sembuh dari traumanya tersebut dan mampu tumbuh berkembang lebih baik (Walsh, 2016).

Resiliensi pada keluarga, terutama orang tua yang memiliki anak disabilitas, mengacu pada berbagai jenis karakteristik antara lain membuat makna positif dari disabilitas, meningkatnya spiritualitas orang tua, kepribadian orang tua, komunikasi antar anggota keluarga, career adaptability, locus of control internal, model pengasuhan sehari-hari, positive affect $(P A)$, dukungan sosial dan keyakinan diri, persepsi kesehatan anak disabilitas, dan koping. Review terhadap stres pengasuhan dan resiliensi pada orang tua yang memiliki anak autis di Asia Tenggara telah dilakukan. Illias., dkk (2018) yaitu mengenai stres pengasuhan dan resiliensi pada orang tua yang memiliki anak autis (ASD) di kawasan Asia Tenggara. Selain itu, Kaur (2015) dan McConnell \& Savage (2015) telah melakukan review beberapa jurnal peneltian dari rentang tahun 20102015 tentang stres dan resiliensi dalam keluarga yang mempunyai anak disabilitas intelektual.

Beberapa jurnal yang me-review tentang perkembangan resiliensi pada 
keluarga juga telah dilakukan oleh Walsh (2016). Selanjutnya, Hadizad, Sajedi, Movallali, \& Soltani (2016) telah melakukan penelitian tentang keefektifan pelatihan resiliensi untuk meningkatkan hubungan antara ibu dan anak retardasi mental. Review jurnal, juga telah dilakukan oleh (Ungar, 2015) mengenai variasi pola resiliensi keluarga pada situasi yang menantang, namun belum terdapat review jurnal tentang resiliensi keluarga dan berfokus pada mereka yang mempunyai anak dengan berbagai macam disabilitas.

Dengan demikian, penting untuk melakukan review terhadap hasil-hasil penelitian tentang karakteristik resiliensi keluarga yang mempunyai anak disabililitas. Oleh karena itu, review ini bertujuan untuk memberikan gambaran dari 11 jurnal yang dipublikasi internasional dimulai tahun 2015-2018. Karakteristik subjek, disabilitas anak, dan rancangan penelitian yang digunakan dalam penelitian akan direview untuk rekomendasi selanjutnya di Indonesia, sehingga hasil ini akan memberikan kontribusi dan rujukan terhadap kesejahteraan keluarga secara praktis dan teoritis.

\section{METODE PENELITIAN}

Pencarian sistematik dilakukan dengan mencari tema yang relevan melalui sistem elektronik dilakukan untuk mengidentifikasi beberapa penelitian tentang resiliensi keluarga yang mempunyai anak disabilitas. Menggunakan website wileyonlinelibrary.com, googleschoolar.com, searchebscohost.com, www.gen.lib.rus.ec, dan researchgate.net.

Kata kunci yang dilakukan dalam pencarian jurnal ini ialah, disability, resiliency, family. Melalui kata kunci tersebut, didapatkan sejumlah jurnal selanjutnya dilakukan seleksi sesuai kriteria yang telah ditentukan. Penentuan tahun dalam menentukan review literatur dimulai tahun 2015 hingga 2018. Melalui abstrak dilakukan review, sehingga dapat teridentifikasi penelitian yang sesuai. Hanya jurnal berbahasa inggris yang digunakan.

Sebanyak 11 jurnal hasil penelitian didapatkan. Kriteria keluarga yang digunakan dalam penelitian ini, ialah keluarga kandung maupun angkat, dan bukan pengasuh. Sedangkan pada anak disabilitas, seluruh kriteria anak disabilitas digunakan untuk review.

\section{HASIL REVIEW DAN PEMBAHASAN}

Setelah dilakukannya tinjauan terhadap 11 jurnal dari hasil penelitian mengenai resiliensi keluarga yang memiliki anak disabilitas, selanjutnya terdapat ringkasan yang ditujukan untuk mendapatkan gambaran keseluruhan 
mengenai isi dari jurnal hasil penelitian

kecenderungan hasil-hasil penelitian yang yang telah di review. Berikut telah dilakukan.

Tabel 1. Ringkasan Karakteristik Hasil Penelitian

\begin{tabular}{|c|c|c|c|c|}
\hline $\begin{array}{l}\text { Peneliti \& } \\
\text { Tahun }\end{array}$ & $\begin{array}{c}\text { Jumlah \& Usia } \\
\text { Subjek }\end{array}$ & $\mathbf{X}$ & $\mathbf{Y}$ & $\begin{array}{c}\text { Karakteristik } \\
\text { ABK }\end{array}$ \\
\hline $\begin{array}{l}\text { Sinha, D., } \\
\text { Nitisha V., \& } \\
\text { Devavrat H. } \\
\text { (2016) }\end{array}$ & $\begin{array}{l}98 \text { orang tua ( } 53 \\
\text { ibu, } 45 \text { ayah) }\end{array}$ & $\begin{array}{l}\text { Pola pengasuhan, } \\
\text { stres dalam } \\
\text { pengasuhan, dan } \\
\text { resiliensi }\end{array}$ & & $\begin{array}{l}\text { Orang tua yang } \\
\text { memiliki anak autis } \\
\text { (ASD), kesulitan } \\
\text { belajar, dan tidak } \\
\text { terdapat gangguan }\end{array}$ \\
\hline $\begin{array}{l}\text { Rajan, A. M,. G. } \\
\text { Srikrishna,. \& J. } \\
\text { Romate (2018) }\end{array}$ & $\begin{array}{l}60 \text { orang tua ( } 30 \\
\text { ayah, } 30 \mathrm{ibu} \text { ), } \\
\text { usia } 26-60 \text { tahun. } \\
\text { Usia anak } 5-22 \\
\text { tahun }\end{array}$ & $\begin{array}{l}\text { Resiliensi dan } \\
\text { Locus of Control }\end{array}$ & & $\begin{array}{l}\text { Anak dengan } \\
\text { disabilitas } \\
\text { intelektual }\end{array}$ \\
\hline $\begin{array}{l}\text { Mohan, R.. \& } \\
\text { Kulkarni M. } \\
\text { (2018) }\end{array}$ & $\begin{array}{l}32 \text { orang tua ( } 29 \\
\text { ibu dan } 3 \text { ayah), } \\
\text { usia } 21-70 \text { tahun. }\end{array}$ & $\begin{array}{l}\text { Resiliensi pada } \\
\text { orang tua }\end{array}$ & & $\begin{array}{l}\text { Anak dengan } \\
\text { disabilitas } \\
\text { intelektual }\end{array}$ \\
\hline $\begin{array}{l}\text { Caples, dkk. } \\
\text { (2018) }\end{array}$ & $\begin{array}{l}95 \text { orang tua ( } 79 \\
\text { ibu, } 16 \text { ayah) usia } \\
28-57 \text { tahun, } \\
\text { dengan anak } \\
\text { down syndrome } \\
\text { yang berusia } 1 \text { - } \\
30 \text { tahun }\end{array}$ & Resiliensi & $\begin{array}{l}\text { Kesejahteraan } \\
\text { orang tua dan } \\
\text { keberfungsian } \\
\text { keluarga }\end{array}$ & Down syndrome \\
\hline $\begin{array}{l}\text { Choi, Eun } \\
\text { Kyoung., \& Il, } \\
\text { Young Yoo. } \\
\text { (2015) }\end{array}$ & $\begin{array}{l}126 \text { orang tua } \\
\text { dengan anak } \\
\text { down syndrome }\end{array}$ & $\begin{array}{l}\text { Resiliensi pada } \\
\text { keluarga }\end{array}$ & & Down syndrome \\
\hline $\begin{array}{l}\text { Hillman, J., } \\
\text { Marvin., \& } \\
\text { Anderson (2016) }\end{array}$ & $\begin{array}{l}1870 \text { kakek \& } \\
\text { nenek (1.524 } \\
\text { nenek, } 346 \\
\text { kakek), usia } \\
\text { kurang lebih } 65 \\
\text { tahun }\end{array}$ & $\begin{array}{l}\text { Pengalaman, } \\
\text { kontribusi, dan } \\
\text { resiliensi pada } \\
\text { kakek \& nenek }\end{array}$ & & Anak autis (ASD) \\
\hline $\begin{array}{l}\text { Kadi, S., \& } \\
\text { Muzeyyen, E. C. } \\
\text { (2018) }\end{array}$ & $\begin{array}{l}222 \text { orang tua } \\
\text { (183 perempuan, } \\
39 \text { laki-laki), usia } \\
21 \text { ke atas }\end{array}$ & $\begin{array}{l}\text { Tingkat resiliensi } \\
\text { orang tua }\end{array}$ & & Anak disabilitas \\
\hline $\begin{array}{l}\text { Khan, M. Asad., } \\
\text { Rabeea, K., \& } \\
\text { Samar, A. } \\
\text { (2017) }\end{array}$ & $\begin{array}{l}200 \text { ibu usia } 23- \\
52 \text { tahun (100 } \\
\text { yang memiliki } \\
\text { anak ASD, } 100 \\
\text { yang memiliki } \\
\text { anak tanpa } \\
\text { gangguan), usia } \\
\text { anak 3-12 tahun }\end{array}$ & $\begin{array}{l}\text { Resiliensi, } \\
\text { perceived social } \\
\text { support, locus of } \\
\text { control pada ibu }\end{array}$ & & $\begin{array}{l}\text { Anak autis dan } \\
\text { anak yang tidak } \\
\text { memiliki gangguan }\end{array}$ \\
\hline
\end{tabular}




\begin{tabular}{|c|c|c|c|c|}
\hline $\begin{array}{l}\text { Rea-Amaya., G. } \\
\text { A., \& Gabriela, } \\
\text { O. V. (2017) }\end{array}$ & $\begin{array}{l}80 \text { orang tua (16 } \\
\text { ayah, } 58 \mathrm{ibu}, 4 \\
\text { nenek, } 2 \text { bibi) } \\
\text { usia orang tua } \\
\text { (wanita) } 23-60 \\
\text { tahun, usia orang } \\
\text { tua (laki-laki) } 27- \\
53 \text { tahun }\end{array}$ & $\begin{array}{l}\text { Potensi faktor } \\
\text { resiliensi pada } \\
\text { orang tua }\end{array}$ & $\begin{array}{l}\text { Keberfungsian } \\
\text { keluarga dan } \\
\text { acceptance of } \\
\text { disability }\end{array}$ & ASD \\
\hline $\begin{array}{l}\text { Richardson, E } \\
\text { Winkelman,. \& } \\
\text { Z, Stoneman. } \\
\text { (2015) }\end{array}$ & $\begin{array}{l}9 \text { orang tua yang } \\
\text { memiliki anak } \\
\text { disabilitas dan } \\
\text { masuk dalam } \\
\text { komunitas agama } \\
\text { Kristen }\end{array}$ & $\begin{array}{l}\text { Resiliensi dalam } \\
\text { mencari dan } \\
\text { mempertahankan } \\
\text { keanggotaan pada } \\
\text { komunitas agama } \\
\text { (faith } \\
\text { communities) }\end{array}$ & & Anak disabilitas \\
\hline $\begin{array}{l}\text { John \& Roblyer. } \\
\text { (2017) }\end{array}$ & $\begin{array}{l}47 \text { ibu yang } \\
\text { mempunyai anak } \\
\text { dengan usia 3-6 } \\
\text { tahun }\end{array}$ & Pengasuhan Ibu & & $\begin{array}{l}\text { Disabilitas } \\
\text { intelektual }\end{array}$ \\
\hline
\end{tabular}

Berdasarkan hasil ringkasan dari beberapa karakteristik jurnal hasil penelitian, selanjutnya akan dilakukan pembahasan dan rekomendasi tentang berbagai kemungkinan penelitian yang dapat dilakukan di Indonesia.

\section{Karakteristik Subjek Penelitian dan}

\section{Sasaran Penelitian}

Berdasarkan hasil dari 11 jurnal penelitian, terdapat 3 penelitian yang membahas tentang resiliensi keluarga yang memiliki anak disabilitas intelektual, 4 anak autis (ASD), 2 down syndrome, 1 kesulitan belajar, dan selebihnya keluarga yang mempunyai anak disabilitas lain. Status anak dalam keluarga, terdapat anak kandung dan anak angkat. Rata-rata usia anak disabilitas yaitu 5 - 30 tahun, dengan urutan kelahiran anak tunggal, anak pertama, anak kedua, dan anak terakhir.

Sebanyak $70 \%$ anak-anak tinggal dengan keluarga intinya dan sisanya, tinggal dengan joint family. Lamanya tinggal dengan anak yang telah terdiagnosa, kurang lebih 11 tahun

Pada karakteristik disabilitas anak, didapatkan hasil bahwa penelitian yang menyoroti disabilitas intelektual terdapat kategori ringan dan sedang. Sedangkan 
pada jenis disabilitas lain, tidak disebutkan kategori disabilitasnya.

Usia subjek pada penelitian ini berkisar antara 21 hingga 70 tahun yang terdiri dari ayah, ibu, kakek, nenek dan bibi. Keluarga yang dikarakteristikkan ialah keluarga yang memiliki pasangan, dan tidak memiliki pasangan (yang dapat dicirikan sebagai single, cerai, dan pasangannya telah meninggal). Karakteristik latar belakang pendidikan keluarga dalam artikel ini ialah, lulusan sarjana, dan sekolah menengah, sedangkan pada sosio-ekonominya beberapa dari mereka mempunyai pendapatan tinggi dan rendah.

\section{Rancangan Penelitian dan Jumlah}

Subjek

Rancangan penelitian yang paling banyak dilakukan ialah survey atau kuantitatif dengan jumlah 6 penelitian, 3 penelitian dilakukan dengan metode kualitatif yaitu wawancara, dan selebihnya penelitian dilakukan dengan metode komparatif dan self-administrated.
Penelitian survey yang dilakukan oleh Rajan, Srikhrisna, \& Romate (2016); Caples, dkk (2018); (Hillman, Marvin, \& Anderson (2016); Kadi \& Cetin (2018) melibatkan kurang lebih 60 hingga 222 orang tua dan 1.870 kakek dan nenek dalam suatu keluarga. Pada penelitian ini, tujuan dari pengukuran berdasarkan metode kuantitaif survey ialah untuk mengembangkan skala resiliensi untuk keluarga, dengan menilai aitem dan faktorfaktornya terhadap berbagai jenis stresor. Namun demikian, akan lebih ideal dan lengkap jika menambahkan metode longitudinal (Haan., dkk. 2002) sehingga dapat dipahami faktor yang paling berpengaruh pada resiliensi keluarga yang mempunyai anak berkebutuhan khusus pada sebelum, sesaat, dan setelah situasi yang menantang terjadi pada kehidupan sehari-hari. Penelitian serupa yang dilakukan oleh Choi \& Il (2015) dengan metode kuisioner berupa selfadministrated, mendapatkan jumlah subjek sebanyak 126 orang tua. 
Penelitian komparatif yang dilakukan oleh Sinha, Nitisha, Devavrat (2016) dan Khan., dkk (2017), membandingkan resiliensi antara keluarga yang mempunyai anak normal dengan keluarga yang memiliki anak disabilitas seperti autis (ASD) dan kesulitan belajar. Didapatkan sekitar 98-200 orang tua yang memiliki anak disabilitas dan yang memiliki anak tanpa disabilitas.

Penelitian kualitatif yang dilakukan oleh Mohan \& Kulkarni (2018); John \& Roblyer (2017); Richardson \& Stoneman (2015), mengambil subjek penelitian sekitar 9 hingga 47 orang tua. Penelitian ini menggunakan metode kualitatif, dengan demikian dapat mengembangkan suatu teori baru mengenai resiliensi pada keluarga dengan anak disabilitas yang sesuai dengan konteks pada penelitian yang dilakukan. Hasil dari beberapa penelitian terhadap resiliensi pada keluarga yang mempunyai anak disabiltas sangat beragam. Pada penelitian kualitatif, hal ini menjadi suatu pemahaman baru mengenai perspektif keluarga dalam menghadapi situasi yang menantang setiap hari. Meskipun demikian, penelitian survey menjadi alternatif yang dapat dipilih untuk mengetahui sejauh mana resiliensi berperan dalam keluarga yang memiliki anak disabilitas.

\section{PEMBAHASAN}

Resiliensi telah menjadi sebuah konsep yang dijadikan sebagai landasan untuk penelitian sebelumnya mengenai keluarga yang mempunyai anak dengan disabilitas (Bayat, 2007). Perbedaan orang tua untuk merespon terhadap situasi stres dalam membesarkan anak disabilitas dapat dipahami dari perspektif resiliensi (Olsson, 2008). Resiliensi dalam perspektif ini, dapat didefinisikan sebagai adaptasi yang baik di dalam keluarga sehingga dapat menurunkan stres, dengan demikian kesejahteraan (wellbeing) mereka meningkat. Menurut Walsh (2010), keluarga resilien tidak selalu berhasil melewati krisis tanpa adanya emosi negatif, tetapi mereka "berjuang dengan baik". 
Resiliensi pada keluarga telah dibuktikan pada hal yang berkaitan dengan hasil individu dan keluarga untuk lebih positif dalam berbagai konteks dan populasi subjek (Fernandez., dkk, 2013; Walsh, 2012). Ibu memegang peranan tanggung jawab yang mendasar dalam menjaga keseimbangan hubungan psikososial, karena dianggap memiliki hubungan yang dekat dengan anaknya (Koohsali M., dkk dalam Hadizad., dkk, 2016).

\section{Walsh Family Resilience}

Framework mengidentifikasi sembilan proses utama resiliensi pada keluarga yang terbagi menjadi tiga domain fungsi keluarga, antara lain:

1. Sistem kepercayaan keluarga, dapat dijelaskan melalui membantu anggota keluarga, membuat makna pada sebuah pengalaman, mempertahankan harapan, memilki pandangan yang positif, dan memanfaatkan nilai-nilai, praktik spiritual.

2. Pola organisasi yang dapat dijelaskan melalui keterhubungan yang saling mendukung, kepemimpinan yang kuat dan fleksibel, sumber daya keluarga, dan komunitas yang luas.

3. Proses komunikasi yang dapat dijelaskan melalui, kejelasan informasi, berbagai emosi yang menyenangkan dan menyedihkan, memecahkan masalah secara kolaboratif dengan pendekatan proaktif untuk siap dalam menghadapi tantangan di masa depan (Walsh, 2014).

$$
\text { Beberapa faktor yang }
$$

mempengaruhi pertumbuhan dan perkembangan pada hubungan dengan anaknya ini, seperti kepribadian ibu, dan interaksi dengan anaknya merupakan hal yang penting (Amir, F., dkk dalam Hadizad., dkk, 2016). Namun dengan demikian, peranan anggota kelurga lainnya juga tidak kalah penting dalam mengasuh anak disabilitas agar nantinya mereka mampu terbiasa dalam berinteraksi dengan orang lain, selain ibu.

Penelitian yang dilakukan oleh Sinha, Nitisha, Devavrat (2016) ibu 
menghabiskan waktu yang banyak (selama

7 jam) dengan anaknya dibandingkan dengan ayah (selama 4 jam). Menghabiskan

lebih banyak waktu dengan anak dikaitkan dengan lebih banyak stres pada orang tua yaitu ibu rumah tangga atau orang tua yang menganggur atau orang tua yang bekerja secara sementara. Wajar jika kebutuhan anak penyandang disabilitas seringkali multidimensi dan satu orang tua tunggal atau orang tua yang menganggur dapat menghadapi beban besar dalam pengasuhan anak. Meskipun, stres orang tua dipengaruhi oleh diagnosis anak, namun tidak dengan resiliensinya. Penelitian ini juga menunjukkan bahwa orang tua yang memiliki anak tidak disabilitas melaporkan tingkat resiliensi yang sebanding, seperti halnya orang tua dengan anak autis dan kesulitan berbahasa (Sinha, Nitisha, Devavrat, 2016).

Stres yang dialami ibu sangat signifikan dengan parental factor seperti, peran orang tua, sense of competence, dan hubungan dengan pasangan. Parental stress sangat tinggi pada anak-anak dengan usia yang lebih muda dan pada anak laki-laki. Jenis kelamin anak memainkan peran penting di negara seperti India dengan struktur budayanya yang luas. Faktor yang menyumbang pada parental stress yaitu ketidaksadaran tentang penyakit dan pentingnya untuk mengakses ke layanan kesehatan yang berkualitas, ketidaksadaran tentang gejala fisik, psikis, dan kognitif dari gangguan perkembangan, dan terdapat stigma sosial terhadap anak dengan gangguan perkembangan (Sinha, Nitisha, Devavrat, 2016).

$$
\text { Satu-satunya faktor yang }
$$

mempengaruhi resiliensi pada orangtua adalah tipe pengasuhan. Nilai rata-rata resiliensi sangat signifikan pada tipe pengasuhan authoritative, permmisive, dan authoritarian. Faktor-faktor yang membedakan ketiganya adalah kehangatan dan kontrol. Resiliensi menjadi yang yang paling tinggi nilainya pada orang tua yang authoritative dan paling redah pada orang tua yang authoritarian. Tingkat kehangatan 
menurun dari authoritative menjadi

permmisive, kemudian orang tua dengan tipe pengasuhan authoritarian. Hal ini dapat dihipotesiskan bahwa perasaan kehangatan terhadap anak lebih dari kontrol yang mempengaruhi resiliensi orangtua.

Siklus resiliensi dalam keluarga, berfokus pada adaptasi terhadap peristiwa kritis dan transisi yang besar, hal ini termasuk kehadiran anak berkebutuhan khusus. Kumpulan stressor yang berasal dari internal dan eksternal dapat meningkatkan kerentanan dan timbul resiko pada masalah-masalah berikutnya (Patterson, 2002). Kesulitan yang dihadapi oleh keluarga, dapat terjadi ketika anggota keluarga gagal dalam menghadapi krisis atau tekanan yang komulatif(Walsh, 2007).

$$
\text { Berbagai upaya untuk }
$$

meningkatkan resiliensi pada keluarga, yaitu dengan meyelaraskan kembali peran fungsional pada anggota keluarga, memiliki jaringan sosial yang luas, memiliki pendapatan yang cukup, dan mengurangi ketegangan dalam sebuah relasi yang ada dalam keluarga maupun di luar keluarga, (Walsh, 2016). Ketegangan yang terjadi dalam keluarga ialah meningkatnya biaya pengobatan dan pendidikan dan meningkatnya kesulitan dalam mengelola anak-anak, hal ini berpengaruh terhdap keberfungsian keluarga (Caples., dkk, 2018).

Keberfungsian keluarga, dapat ditunjukkan melalui indikator adaptasi dan resilien. Proses dalam keluarga yang terpenting ialah memfasilitasi dalam beradaptasi untuk jangka waktu yang panjang melalui pengakuan bersama anggota keluarga, dan membuat makna bersama. Caples., dkk (2018) mengidentifikasi komunikasi afirmatif, family hardiness, dan tekanan keluarga sebagai faktor penting. Menggunakan teknik komunikasi afirmasi positif melalui orang yang professional, dapat memengaruhi gaya komunikasi dalam keluarga dan berpotensi membatasi dampak komunikasi yang mampu meregangkan anggota keluarga 
Prinsip utama resiliensi pada

keluarga meliputi kekuatan dan resiliensi

anggota keluarga, kerja sama, dan stabilitas.

Memperkuat resiliensi pada keluarga dapat

berdampak positif terhadap adaptasi

keluarga. Penyediaan layanan yang

berpusat pada keluarga, dengan

memberikan dukungan dan informasi yang

disesuaikan bagi keluarga, dapat

meningkatkan resiliensi keluarga dan

meningkatkan fungsi sebuah keluarga

(Caples., dkk, 2018). Pentingnya

keberfungsian keluarga, merupakan kunci

bagi kesejahteraan anak dan orang tua

dalam menghadapi situasi yang menantang

di setiap harinya. Fungsi yang efektif dalam

keluarga dan adaptasi yang positif

bergantung pada jenis dan tingkat kesulitan

terhadap tantangan yang dihadapi, dan

tujuan keluarga dalam menjalani kehidupan

(Walsh, 2016).

Sumber daya yang didapatkan dari

budaya dan spiritual juga mampu

mendukung resiliensi pada individu dan

keluarga (Kirmayer, Dandeneau, Marshall,
Phillips, \& Williamson, 2011; McCubbin \&

McCubbin, dalam Walsh 2016) terutama

bagi mereka yang menghadapi diskriminasi

dan hambatan dalam sosial ekonomi.

Sumber-sumber resiliensi ini, mampu

didapatkan keluarga yang terlibat dalam

jaringan sosial untuk mengatasi kesulitan

yang mungkin akan dihadapi dan konteks

yang kuat untuk memelihara dan

memperkuat resiliensi (Walsh, 2016).

Penelitian yang dilakukan oleh

Mohan \& Kulkarni (2018) pada budaya

India, yang dideskripsikan sebagai

masyarakat kolektivis di mana individu

digolongkan oleh keluarga, komunitas dan

budaya kota atau kota besar.

Kecenderungan umum adalah berbaur

dengan orang lain dari pada harus menonjol

di antara orang lain. Kesehatan mental

sangat penting bagi kesejahteraan individu

secara keseluruhan. Dalam konteks negara

berkembang kemiskinan, ketimpangan dan

berbagai pemicu stres, kemampuan untuk

bertahan hidup dan berkembang

membutuhkan ketahanan. 
Sedangkan pada negara yang maju seperti Korea, orang tua bertanggung jawab penuh atas perawatan anak mereka karena program dukungan untuk anak-anak cacat walaupun di Korea masih sangat terbatas. Namun, banyak keluarga yang mengalami beban keuangan karena mereka harus membayar untuk program dan pendidikan khusus. Dukungan program-program ini, menyebabkan peningkatan ketegangan, stres, kelelahan fisik dan emosional di antara orang tua. Terdapat sikap negatif terhadap perbedaan yang dialami oleh keluuarga, hal ini menjadi sesuatu yang kuat dalam masyarakat Korea karena memiliki kelompok orang yang sangat homogen. Tidak banyak etnis keragaman di Korea dan kadang-kadang kurangnya kesempatan untuk bertemu orang yang berbeda ini dapat menyebabkan diskriminasi dan isolasi (Choi \& Il, 2015). Resiliensi juga ditemukan berfungsi secara independen pada usia orang tua, jenis kelamin, waktu yang dihabiskan untuk tinggal dengan anak setelah didiagnosis disabilitas, usia anak, jenis kelamin anak, dan IQ nya. Pada penelitian yang dilakukan, peneliti berfokus pada kekuatan internal yang dimiliki oleh orang tua pada saat merawat dan membesarkan anak disabilitas intelektual. Usia berkaitan dengan pertumbuhan fisik, pubertas, dan perubahan psikologis lainnya memiliki kecenderungan menjadi penyebab utama stres pada orang tua. Yang sama pentingnya adalah proses penuaan orang tua, yang memberi dampak psikologis tersendiri pada orang tua (Sinha, Nitisha, Devavrat, 2016).

Penelitian yang dilakukan oleh Rajan, Srikhrisna, \& Romate (2016) menunjukkan tidak ada hubungan antara resiliensi dengan usia orang tua dan anak, lamanya tinggal dengan anak setelah di diagnosis, jenis kelamin, dan IQ. Resiliensi beroperasi secara independen dari faktorfaktor demografis dapat dijelaskan dalam pendekatan siklus hidup yang menyatakan bahwa ada tugas perkembangan yang perlu dikuasai orang tua, dalam kaitannya dengan anak penyandang cacat di setiap tahap 
perkembangan dan penguasaannya mendorong adaptasi.

Tidak peduli apakah orang tua di usia dewasa atau setengah baya atau apakah anak-anak mereka di masa remaja atau masa kanak-kanak, orang tua dihadapkan dengan tuntutan dan tantangan, yang dapat membuat mereka dalam tekanan. Sebagai anak, melangkah tangga perkembangan, orang tua juga memiliki masalah baru, perjuangan untuk ditangani. Tetapi dampak dari ini dapat bervariasi sehubungan dengan jenis kelamin anak serta orang tua, pendidikan dan tingkat keterbelakangan anak. Jadi menarik makna dari kesulitan tampaknya rumit,unik untuk setiap orang tua dan bervariasi selama periode waktu tertentu. Konsisten dengan ini adalah gagasan saat ini dalam ketahanan, yaitu, adaptasi positif adalah permanen. Hal ini dianggap sebagai proses negosiasi kelemahan dan kekuatan dalam mengubah tahap perkembangan. Dengan demikian, mereka terlibat dalam perilaku yang diarahkan pada tujuan untuk mengatasi keadaan dan kehidupan (Rajan, Srikhrisna, \& Romate, 2016).

Interaksi yang terjadi dalam kehidupan keluarga, dapat dikaitkan antara faktor resiko dan protektif dalam resiliensi pada individu, hal ini dapat bervariasi. (Olsson, Bond, Burns, Vella-Brodrick, \& Sawyer, 2003). Penelitian yang menguji faktor-faktor potensial pada orang tua denagn anak autis (ASD) juga dilakukan oleh Rea-Amaya (2017), didapatkan hasil bahwa ketika orang tua memberikan makna pada kehidupan mereka dan dapat mencari bantuan untuk menyelesaikan masalah, maka ikatan emosional keluarga menjadi kuat. Namun ketika mereka menunjukkan kesulitan, kesusahan, kesedihan atas peristiwa yang dialami, sedikit sekali tolerasi dan ketidakkonsistenan dalam keluarga.

Lebih lanjut, faktor - faktor resiliensi dapat dikategorikan menjadi tiga, antara lain individu, sosial, dan lingkungan. Pada tingkat individu, terdapat kepercayaan pribadi, karakteristik, dan kemampuan 
seperti persepsi diri yang positif, sense of meaning life, dan locus of control (Bekhet., dkk, 2012; Friborg., dkk, 2006; Olsson., dkk, 2003). Pada tingkat sosial terdapat kohesi keluarga, hubungan antar anggota keluarga, kompetensi sosial, dan dukungan sosial. Selanjutnya pada tingkat lingkungan, adanya afiliasi dalam organisasi (Bekhet., dkk, 2012; Friborg., dkk, 2006). Dengan demikian, adanya beberapa faktor protektif ini dapat mengantarkan individu ataupun keluarga yang memiliki anak berkebutuhan khusus menjadi lebih positif.

Merujuk pada tingkat individu, penelitan yang dilakukan oleh Rajan, Srikhrisna, \& Romate (2016) menunjukkan bahwa perbedaan dalam latar belakang pendidikan orang tua sangat berpengaruh secara signifikan terhadap resiliensi keluarga. Bagi orang tua yang memiliki latar belakang pendidikan yang tinggi, mempunyai kesadaran dan pemahaman untuk mengatasi tuntutan yang diperlukan bagi anak disabilitas. Orang tua melakukan upaya seperti menemukan kemampuan anak dan mencari orang yang professional sebagai bentuk tersedianya layanan yang dibutuhkan untuk anak disabilitas. Faktor karakteristik individu lainnya mengenai pengalaman orangtua dalam mengasuh anak berkebutuhan khusus, diantaranya adaptasi kognitif, positive affect, dukungan sosial, dan efikasi diri (Mohan \& Kulkarni, 2018).

Aspek kognitif, menjadi peranan penting anggota keluarga dalam mengasuh anak disabilitas. Penelitian yang dilakukan oleh Khan., dkk (2017) menunjukkan perbedaan yang signifikan pada resiliensi dan locus of control pada ibu yang memiliki anak dengan kategori disabilitas autis (ASD) dan anak yang tidak memiliki kategori disabilitas. Namun tidak terdapat perbedaan yang signifikan pada kedua kelompok terhadap resiliensi dan dukungan sosial. para ibu, memanfaatkan informasi yang didasarkan pada fakta dan agama untuk memahami disabilitas yang dialami oleh anak mereka. Hal ini senada dengan 
penelitian yang dilakukan oleh Richardson

\& Stoneman (2015), menjelaskan bahwa sebuah anggota dalam komunitas agama menunjukkan pengalaman yang positif, mampu memiliki pandangan yang positif terhadap pengalaman yang negatif dan menjadi keanggotaan yang sepenuhnya mengikuti komunitas agama mereka. Hal ini dapat menjadi bukti bahwa spiritualitas memegang peranan penting dalam resiliensi individu (John \& Roblyer, 2017).

Penelitian yang dilakukan oleh Caples., dkk (2018); Choi \& Il (2015) menunjukkan bahwa terdapat faktor-faktor yang berpengaruh terhadap pengasuhan anak down syndrome. Faktor positif yang berpengaruh yaitu family hardiness, dukungan komunikasi keluarga, kesehatan orang tua, kekompakan dalam sebuah keluarga, fleksibel dalam keterampilan berkomunikasi, adanya keluarga yang mendukung, dan kualitas pelayanan pada masyarakat. Sedangkan faktor yang berpengaruh negatif ialah incendiary family communication, pandangan tentang dampak dari kondisi yang dimiliki, usia anak, tingkat perkembangan anak, depresi orang tua, stres orang tua, dan ketegangan dalam sebuah hubungan, terhadap adaptasi keluarga.

Karakteristik yang berhubungan dengan anak seperti mobilitas dan masalah perilaku, ketersediaan dukungan sosial, masalah keluarga, Kesadaran sebelumnya tentang kondisi keterbelakangan mental dari diagnosis yang diterima, mempengaruhi adaptasi dan pengaruh kognitif. Hal ini membentuk lingkaran umpan balik dengan coping dan selfefficacy. Putaran umpan balik ini ditandai sebagai resiliensi (Mohan \& Kulkarni, 2018). Penelitian komparatif, dengan membandingkan sub grup pada kategori demografis dilakukan oleh Kadi, S., \& Muzeyyen, E. C. (2018), didapatkan hasil bahwa tidak ada perbedaan antar sub grup diantaranya, jenis kelamin anak-anak, usia anak, dukungan yang diterima untuk pengasuhan, masalah kesehatan orang tua, dukungan psikologis, usia orang tua, tingkat 
pendapatan dan pendidikan orang tua terhadap disabilitas ganda (lebih dari satu disabilitas yang dialami oleh anak). Namun terdapat perbedaan yang signifikan pada dimensi tantangan berdasarkan jenis kelamin orang tua dan jenis disabilitas anak. Berdasarkan faktor-faktor resiliensi, merujuk pada tingkatan sosial peran anggota keluarga besar seperti kakek, menjadi hal yang penting untuk resiliensi keluarga. Penelitian yang dilakukan oleh Hillman, Marvin, \& Anderson (2016) dengan metode serupa mengungkapkan bahwa anggota keluarga terutama kakek memberikan kontribusi uang yang sangat berpengaruh untuk kebutuhan teraupeutik bagi cucunya yang mengalami autism, mereka juga memiliki koping yang sangat baik terhadap cucunya walaupun terdapat kekhawatiran terhadap kesejahteraan pada saat dewasa nanti.

Kecenderungan dalam beberapa hasil penelitian untuk melihat resiliensi pada keluarga, banyak terdapat pada keluarga yang memiliki anak autis (ASD).
Penelitian yang mereview pada keluarga yang memiliki anak autis (ASD) juga telah dilakukan oleh Illias, dkk., di Asia Tenggara (2018) di kawasan Brunei sebanyak 1 orang, Indonesia 2, Malaysia 12, Filipina 5, Singapura 5, Thailand 2, Vietnam 1.

Selanjutnya, 12 jurnal teah direview oleh McConnell \& Savage (2015) mengenai resiliensi keluarga yang memilki anak berkebutuhan khusus. Dapat dilihat bahwa adanya penelitian yang berfokus pada resiliensi keluarga dengan berbagai karakteristik anak disabilitas meningkat di setiap tahun, hal ini kemungkinan disebabkan adanya prevalensi anak yang menderita disabilitas. Berdasarkan data dari Badan Pusat Statistik Nasional hingga pada tahun 2017 mencapai 1,6 juta anak (Kemendikbud, 2017) dengan demikian merupakan suatu fokus permasalahan pada sebuah keluarga dalam merawat, mengasuh, dan mempersiapkan masa depan anak mereka. 
Sasaran dalam beberapa hasil jurnal penelitian ini, lebih banyak mengacu pada faktor protektif resiliensi keluarga yang paling berpengaruh terhadap keberhasilannya mengasuh anak dalam mengatasi situasi yang menantang di setiap harinya. Faktor yang paling berpengaruh pada resiliensi keluarga ini ialah keagamaan atau religiusitas, locus of control, koping, keberfungsian keluarga, komunikasi antar anggota, kesadaran diri, dukungan sosial.

$$
\text { Resiliensi dapat dilihat dalam }
$$
berbagai hal, yang pertama resiliensi dipandang sebagai sebuah hasil dari pola perilaku yang kompeten pada individu dalam situasi yang beresiko, sehingga memungkinkan mereka untuk terus berfungsi dengan baik. Selain itu, ketika resiliensi dipandang sebagai sebuah proses, yaitu adanya mekanisme yang dapat memodifikasi dampak dari situasi yang beresiko, sehingga hal ini dapat memungkinkan individu untuk sukses dalam beradaptasi, dan yang terakhir resiliensi dipandang sebagai konsep yang multifaktor, hal ini menekankan interaksi berbagai faktor resiko dan faktor protektif dalam menghadapi kesulitan.

Menurut Walsh (2002) resiliensi pada keluarga mengacu pada beberapa karakteristik, antara lain sistem kepercayaan yang ada pada keluarga (seperti mempunyai makna akan hal sedang terjadi, pendangan positif, religiusitas), fleksibilitas, keterhubungan, sumber daya sosial dan eknomi, kejelasan (clarity), keterbukaan ekspresi emosi dan komunikasi, pemecahan masalah.

Berdasarkan pemaparan yang telah dilakukan, dapat direkomendasikan penelitian tentang resiliensi dalam berbagai karakteristik demografis yang lebih luas. Selain itu, ditambahkan juga variabel budaya atau suku untuk melihat gambaran resiliensi pada keluarga.

\section{KESIMPULAN DAN SARAN \\ Berdasarkan beberapa penelitian yang telah dilakukan, dapat disimpulkan bahwa resiliensi pada keluarga sangat}


penting bagi kelangsungan hidup anak-anak disabilitas. Beberapa faktor yang mempengaruhi resiliensi pada keluarga ialah keagamaan atau religiusitas, locus of control, koping, keberfungsian keluarga, komunikasi antar anggota, kesadaran diri, dukungan sosial.

Saran yang diberikan dalam artikel ini ialah, melakukan penelitian pada berbagai metode dengan menambahkan variabel religiusitas dan budaya. Mengingat bahwa Indonesia memiliki beragam suku dan budaya. Resiliensi sendiri terbentuk karena adanya adaptasi, pola perilaku dan kognitif yang dipengaruhi oleh faktor eksternal dan internal pada sebuah keluarga.

\section{DISKUSI}

Perhatian tentang resiliensi keluarga yang memiliki anak disabilitas berkembang sehingga mempunyai kontribusi secara teoritis dan praktis. Secara praktis, menambah wawasan pada keluarga untuk berdasarkan penelitian yang elah dilakukan

mengasuh dan merawat anaknya dengan tepat sehingga anak merasa nyaman dengan keluarganya, dapat berpengaruh pada kesehatan dan masa depannya. Sedangkan secara teoritis, dapat mengembangkan teori resiliensi keluarga yang efektif dalam merawat dan mengasuh anak disabilitas.

Adanya temuan yang menunjukkan bahwa terdapat ketidakkonsistensian dan sedikit toleransi pada keluarga yang memiliki anak disabilitas, ketika memikirkan dan melihat ketidakberdayaan pada anak mereka. Hal ini dapat menjadi celah bagi sebuah keluarga untuk menjadi tidak resilien dan berpengaruh pada keluarga dan anak itu sendiri. Oleh karena itu, beberapa temuan lain tentang pelatihan untuk meningkatkan resiliensi pada anggota keluarga, dapat dijadikan solusi untuk mencegah terjadinya ketidakberfungsian sebuah keluarga.

Diberlakukannya pelatihan untuk meningkatkan resiliensi pada keluarga alangkah baiknya untuk selalu dilakukan secara terjadwal, dengan demikian 
ketahanan sebuah keluarga akan selalu terjaga, selain itu merekrut dan mengikuti komunitas yang sesuai dengan kebutuhan keluarga juga dapat mencegah resiliensi keluarga yang rendah. Kategori tingkatan anak disabiltas dalam peneltian yang telah dilakukan, juga dapat ditambahkan untuk menjadi analisis tambahan. Hal ini dapat dijadikan sebagai kekuatan dalam keluarga untuk meningkatkan potensi anak mereka yang sesuai dengan level disabilitasnya.

\section{DAFTAR PUSTAKA}

Azari, Z., \& Mohammadi, M. 2016. Compare resilience of familes with mentally retarded children and family with normal children. Journal of Administrative Management, Education and Training (JAMET), 12(6), 119-127.

Bayat, M. 2007. Evidence of resilience in families of children with autism. Journal of Intellectual Disability Research, 51(9), 702-714

Bekhet, A. K., Johnson, N. L., \& Zauszniewski, J. A. 2012. Resilience in family members of persons with autism spectrum disorder: A review of the literature.
Issues in Mental Health Nursing, $33,650-656$.

Caples, M., Martin, A.-M., Dalton, C., Marsh, L., Savage, E., Knafl, G., \& Riper, M. V. 2018. Adaptation and resilience in families of individuals with down syndrome living in ireland. $\mathrm{Br} J$ Learn Disabil, 146154. doi:10.1111/bld.12231

Choi, E. K., \& Il, Young Yoo. (2015). Resilience in families of children with down syndrome in korea. International Journal of Nursing Practice, 21, 532-541. doi:10.1111/ijn.12321

Erguun, S., \& Ertem, G. 2012. Difficulties of mothers living with mentally disabled children. Journal of the Pakistani Medical Association, 62(8), 776-780

Fernandez, I. T., Schwartz, J. P., Chun, H., \& Dickson, G. 2013. Family resilience and parenting. In D. Becvar (Ed.), Handbook of family resilience (pp. 119-136). New York, NY: Springer

Friborg,O.,Hjemdal,O.,Rosenvinge,J.H.,M artinussen,M.,Aslaksen,P. M., \& Flaten, M. A. 2006. Resilience as a moderator of pain and stress. Journal of Psychosomatic Research, 61, 213-219. 
Haan, L. D., Hawley, D. R., \& Deal, J. E. 2002. Operationalizing family resilience: a methodological strategy. The American Journal of Family Therapy, 30(4), 275-291. doi:10.1080/01926180290033439

Hadizad, T., Sajedi, F., Movallali, G., \& Soltani, P. R. 2016. Effectiveness of resiliency training in improving mother-child relationship in mothers of children with mental retardation. Iranian Rehabilitation Journal, 14(3), 171-178.

Hillman, J., Marvin, A. R., \& Anderson, C. M. 2016. The experience, contributions, and resilience of grandparents of children with autism spectrum disorder. Journal of Intergenerational Relationship, 14(2),

doi:10.1080/15350770.2016.11607 27

Illias, K., Cornish, K., Kummar, A. S., Park, M. S.-A., \& Golden, K. J. 2018. Parenting stress and resilience parents of children with autism spectrum disorder (ASD) in southeast asia: a systematic review. 9(280), $1-14$. doi:10.3389/fpsyg.2018.00280

John, A., \& Roblyer, M. Z. 2017. Mothers parenting a child with intellectual disability in urban india: an application of the stress and resilience framework. Intellectual And Developmental Disabilities, 55(5), 325-337. doi:10.1352/19349556-55.5.325

Kadi, S., \& Cetin, M. E. 2018. Investigating the resilience levels of parents with multiple disabilities based on different variables. Europan Journal of Educational Research, 7(2), 211-223. doi:10.12973/eujer.7.2.211

Kaur, H. 2015. Resilience among the parents of children with intellectual disability. Indian Journal of Health and Wellbeing, 6(10), 1033-1036.

Kemendikbud. 2017. Sekolah inklusi dan pembangunan SLB dukung pendidikan inklusi. Diambil dari https://www.kemdikbud.go.id/main /blog/2017/02/sekolah-inklusi-danpembangunan-slb-dukungpendidikan-inklusi

Khan, M. A., Kamran, R., \& Ashraf, S. 2017. Resilience, perceived social support and locus of control in mothers of children with autism vs those having normal children. Pakistan Journal of Professional Psychology: Research and Practice, $8(1), 1-13$.

Kim, H.-Y. (2018). The relationship between resilience and parenting 
burden among mothers of children with disability: The mediating effect of the health perception. Asiapacific Journal of Convergent Research Interchange, 4(2), 71-78. doi:10.14257/apjcri.2018.06.08

Kirmayer, 1. J., Dandeneau, s., Marshall, E., Phillips, M. K., \& Williamson, K. J. 2011. Rethinking resilience from indigenous perspectives. Canadian Journal of Psychiatry, 56, 84-91.

McConnell, D., \& Savage, A. 2015. Stress and resilience among families caring for children with intellectual disability: Expanding the research agenda. Curr Dev Disord Rep. doi:10.1007/s40474-015-0040-z

Mohan, R., \& Kulkarni, M. 2018. Resilience in parents of children with intellectual disability. Psychology and Developing Societies, $\quad 30(1), \quad 1-25$. doi:10.1177/097133361774732

Oh S., \& Chang S.J. 2014. Concept analysis: Family resilience. Open Journal of Nursing. 4. 980-990

Olsson, C. A., Bond, L., Burns, J. M., VellaBrodrick, D. A., \& Sawyer, S. M. 2003. Adolescent resilience: A concept analysis. Journal of Adolescence, 26, 1-11.

Olsson, M.B. 2008 Understanding Individual Differences in
Adaptation in Parents of children with intellectual disabilities: A risk and resilience perspective. In L.M. Glidden. (Ed.). International Review of Research in Mental Retardation, 36 (pp. 281-315) Burlington: Academic Press

Patterson, J. 2002. Integrating family resilience and family stress theory. Journal of Marriage and Family, 64, 349-360.

Rajan, A., Srikrishna, G., \& M., Romate, J., (2016). Resilience of parents having children with intellectual disability: Influence of parent and child related demographic factors. Indian Journal of Health and Wellbeing, 7(7), 707-710.

Richardson, E. W., \& Stoneman, Z. 2015. The road to membership: The role of resilience in seeking and maintaining membership in a faith community for families of children with disabilities. Journal of Disability \& Religion, 19(4), 312339.

doi:10.1080/23312521.2015.10934 42

Rutter, M. 1987. Psychosocial resilience and protective mechanisms. American Journal of Orthopsychiatry, 57, 316-331. 
Sinha, D., Verma, Nitisha., \& Hershe, Devavart. 2016. A comparative study of parenting style, parental stress, and resilience among parents of children having autism spectrum disorder, parents of children having specific learning disorder and parents of children not diagnosed with any psychiatric disorder. 2(4). doi: 10.21276/aimdr.2016.2.4.30

Tedeschi, R. G., \& Calhoun, L. G. 2004. Posttraumatic growth: Conceptual foundations and empirical evidence. Psychological Inquiry, 15, 1-18.

Ungar, M. 2015. Varied patterns of family resilience in challenging contexts. Journal of Marital and Family Therapy, 42(1), 19-31. doi:10.1111/jmft.12124

Walsh, F. 2002. A family resilience framework. Family Relations, 51, $130-137$

Walsh, F. 2007. Traumatic loss and major disasters: strengthening family and community resilience. Family Process, 46, 207-227.

Walsh, F. 2010. A family resilience framework for clinical practice: Integrating developmental theory and systemic perspectives. In $\mathrm{W}$. Borden (Ed.), Reshaping theory in contemporary social work: Toward a critical pluralism in clinical practice (pp. 146-176). New York, NY: Columbia University Press

Walsh, F. 2012. Facilitating family resilience: Relational resources for positive youth development in conditions of adversity. In $\mathrm{M}$. Unger (Ed.), The social ecology of resilience: A handbook of theory and practice (pp. 173-186). New York, NY: Springer.

Walsh, F. 2014. A family resilience framework: Principles and applications. Symposium on Family Resilience. 11-29

Walsh, F. 2016. Family resilience: A developmental systems framework. Europan Journal Of Developmental Psychology, $1-12$. doi:10.1080/17405629.2016.11540 35

Walsh, F. 2016. Applying a family resilience framework in training, practice, and research: Mastering the art of the possible. Family Process, 55(4), 616-632. doi:10.1111/famp.12260

Wong, P. K., Fong, K. W., \& Lam, T. L. 2015. Enhancing the resilience of parents of adults with intellectual disability through volunteering: An exploratory study. Journal of Policy and Practice in Intellectual 
Disability,

$1-17$.

doi:10.1111/jppi.12101 